\title{
A First Nation Economic Development Model
}

\author{
Carole Delion
}

Achieving balance is not an easy task for First Nations, as there are numerous obstacles to overcome by manoeuvring through the legislative processes at the federal and provincial jurisdictional levels. The goal of this paper is to explore how to grow a sustainable economic development model within a First Nation, using the example of Aamjiwnaang First Nation, a small community that is located in southern Ontario. It will document the development and evolution of Aamjiwnaang's economic development model, named A Healthy Tree, which is founded on Elder and Aamjiwnaang Chief Gerald Maness, Sr.'s concept of the community as a tree. The paper will demonstrate the steps taken and the best practices used for turning obstacles into opportunities. Finally, it will address a major issue facing the Aamjiwnaang Band Council: how it can proceed when the Head Lease expires in 2025.

Keywords: First Nations, communities, economic development, strategic planning, industrial parks

\section{Introduction}

For First Nations it remains, and continues to be, a great challenge to enhance the social economic environment for the First Nation so that it will foster economic growth for future generations. Gerald Maness Sr, an Elder and Chief from the Aamjiwnaang First Nation who has often been quoted for his wisdom, has said that a healthy community must be like a healthy tree. He believes to grow a healthy tree with a strong root system, it must be well balanced culturally, spiritually, socially, and economically. His vision has inspired many lessons that have been instrumental in moving Aamjiwnaang towards achieving its economic development aspirations. The healthy tree analogy will be woven through each section to continually reinforce the vision.

Achieving balance is not an easy task for First Nations, as there are numerous obstacles to overcome by manoeuvring through the legislative processes at the federal and provincial jurisdictional levels. The goal of this paper is to explore how to grow a sustainable economic development model within a First Nation, using the example of Aamjiwnaang First Nation, a small community that is located in southern Ontario. It will document the development and evolution of Aamjiwnaang's economic development model, named A Healthy Tree, which is founded on Maness' concept of the community as a tree. The paper will demonstrate the steps taken and the best practices used for turning obstacles into opportunities. Finally, it will address a major issue facing the Aamjiwnaang Band Council: how it can proceed when the Head Lease expires in 2025. The issue is described in further detail later in the paper. 


\section{Historical Background}

The Royal Proclamation of 1873 recognized Aboriginal rights and title for nation-to-nation relationships between the Crown and First Nations communities; and these rights were eventually recognized and affirmed under Section 35 of the Canadian Constitution in 1982 (Constitution Act, 1982, s.35). The Indian Act of 1876 has set the framework that today, despite numerous legislative changes, remains fundamentally intact regulating almost every aspect of community life of registered Indians. This has made it extremely difficult for First Nations to participate in the mainstream economy through laws, regulations and "Indian policies" that were imposed upon the First Nations without their input and consent.

While legislation and regulations in off-reserve contexts typically evolves over time, the Indian Act has changed little. As noted by the National Aboriginal Economic Development Board (2013), this has left "on reserve communities with outdated and paternalistic rules and procedures which have not kept pace with modern economy".

\section{Aamjiwnaang's Economic Landscape}

In 1827, the Amherstburg Treaty established four Reserves, which later became First Nations, in what is now Southwestern Ontario. One of these First Nations was the Chippewas of Sarnia, now known as the Aamjiwnaang First Nation. Aamjiwnaang is an Ojibwe word, pronounced am-JIN-nun, which means meeting place by the rapid water. Historically the area of the Treaty lands was approximately 10,000 acres, but it has been reduced to its present size of 3,000 acres through the sale of land, primarily to industry.

In the 1840s, the United States government began to relocate many different First Nations people to "Indian Territory". As a result, a large number of Chippewa, Potawatomi and Odawa who had previously sided with the British migrated to Canada from the United States. The dispossessed First Nations people were eventually allowed to stay in Southern Ontario. While many traveled up to settle on the east and north shores of Lake Huron, many settled on Aamjiwnaang.

At the time of the Treaty of 1827, First Nation interests were looked after by a hereditary Chief and a group of sub-Chiefs. In 1876 legislation provided for the election of Chiefs. Today the Aamjiwnaang First Nation is governed by a Chief and 9 Councillors which are elected every 2 years. This year,Aamjiwnaang elected its first woman Chief, Joanne Rogers.

According to the Aamjiwnaang Membership Clerk, the total population of Aamjiwnaang in 2013 was approximately 2,283, including 945 Members living on the First Nation and 1,338 Members living off the First Nation.

Aamjiwnaang is located is located within the southern boundary of the City of Sarnia adjacent to the St. Clair River in southwestern Ontario (See: Figure 1). It is a unique situation for a First Nation to be located within municipal boundaries. It came about in the early 1950s when the 
petrochemical companies began to expand their sites. Aamjiwnaang is in the heart of Sarnia's Chemical Valley, surrounded by major industrial refineries including Suncor, Trans Alta, Lannex, Imperial Oil and Shell Canada. The adjacent petrochemical industry is a major component of the local economy. It has resulted in the granting of numerous pipeline and hydro easements which cross Aamjiwnaang lands, and provides a source of revenue for the First Nation.

Aamjiwnaang is connected to a number of regional and international transportation corridors, specifically, the 400 series highways and the Bluewater Bridge to the United States. The Chesapeake and Ohio Railway crosses through Aamjiwnaang, connecting to the Paul M. Tellier international railway tunnel in Sarnia. A Canadian National Rail line also passes through Aamjiwnaang that connects to Toronto and United States. There are approximately two kilometres of frontage along the St. Clair River, a significant shipping corridor that connects to the Great Lakes and the St. Lawrence Seaway.

\section{Figure 1. Location of Aamjiwnaang First Nation}

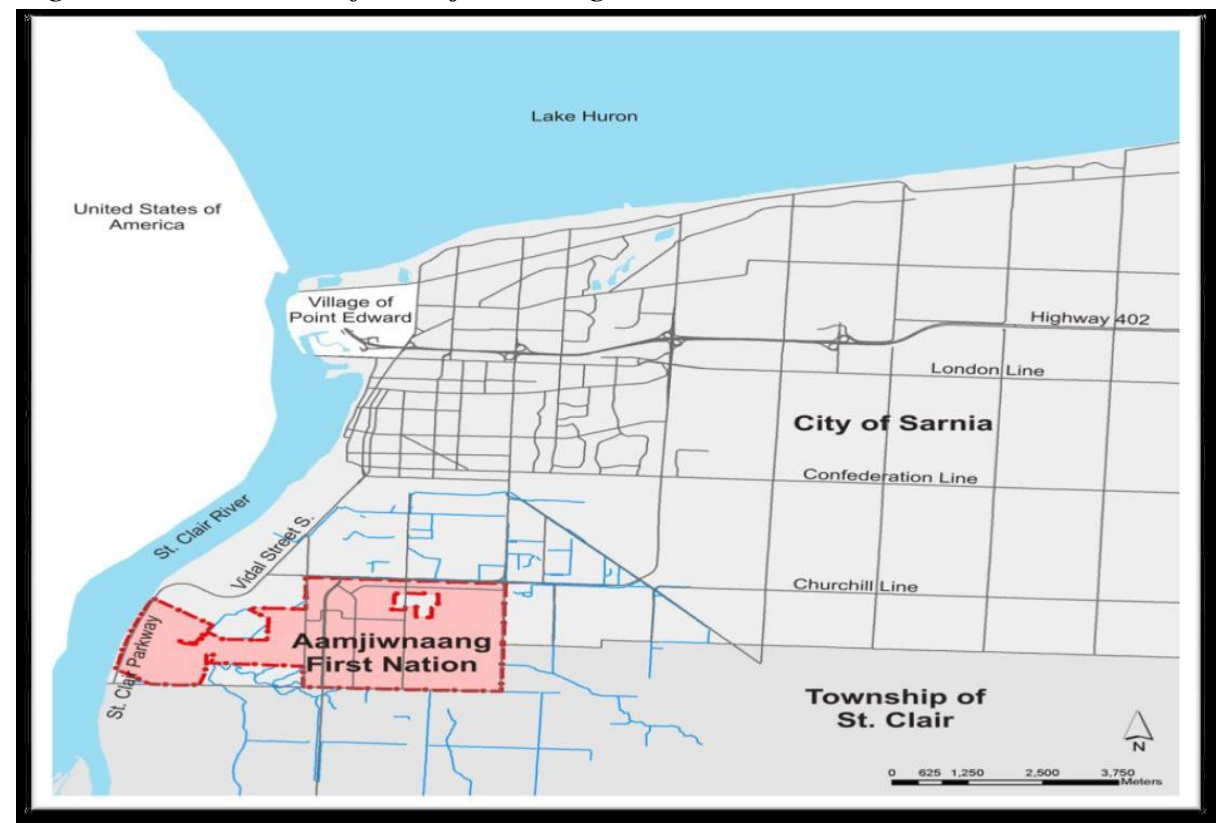

Aamjiwnaang's location has proved to be one of its strongest assets in attracting industrial and commercial development opportunities on First Nation-owned lands and facilitating long-term economic development sustainability.

\section{The model}

In the analogy of growing a healthy tree, the first step is choosing the best place to plant it. For optimal growth, the tree needs to be placed on good soil where it will get exposure to sunshine and protection from the harsh elements. The more thought is put into this step, the more likely it is to succeed. Next, the soil should be cultivated to help the fledgling tree grow. Finally, dead 
branches and sucker roots ${ }^{1}$ will need to be pruned to keep the tree healthy and robust. Done right, all of this care will result in a tree that bears fruit, fruit that contains seeds for future growth and development to sustain future generations.

Aamjiwnaang's economic development model followed a similar formula. It all began with a strategy, a vision if you will, based on the First Nation's assets, challenges and goals. This strategy included an implementation plan to guide vision toward reality. Thanks to these first steps, the model has been able to prune away obstacles and create more opportunity. The overall result has been some success (fruit).

\section{The Plan/Planting the tree}

Aamjiwnaang's leadership has long recognized the potential of First Nation-owned land for industrial use. In 1965, Aamjiwnaang retained Acres and Planning Limited to undertake The Sarnia Reserve Industrial Survey, which identified a large portion of the First Nation as suitable for industrial development of various types. After adopting this report, the First Nation began to assemble approximately 235 acres of land for industrial developments (Jean Monteith \& Associates, 1984). Aamjiwnaang began to set itself apart from other First Nation communities by being progressive to the establishment of an arms-length relationship between industrial development and day-to-day First Nation administration operations. In 1971, it formed a separate corporation, Chippewa Industrial Development Limited (CIDL), to promote and oversee industrial development on the First Nation. CIDL had twelve directors, three of whom were non-aboriginal, chosen for their business and financial experience, and the remaining directors were the Chief and Band Council. CIDL immediately began to arrange the development of a serviced industrial area known as The Chippewa Industrial Park. It is worth noting that only two of the original founding board members actually saw the vision for an industrial park become a reality; as the others have since passed away.

When a First Nation wants to lease out reserve land, the Indian Act requires the land to be set aside or designated for leasing. Aamjiwnaang underwent a lengthy and time consuming designation process. On January 30, 1974 Aamjiwnaang held a Land Designation ${ }^{2}$ vote, reaching consent by its membership. On March 19, 1974 it was accepted by Order in Council. The land, comprising of 28 acres (Phase 1-Chippewa Industrial Park), was officially surrendered for leasing purposes on August 6, 1974. The Land Designation process will be explained further in the 'Options for moving forward with the expiry of Phase One Head Lease' section below.

\footnotetext{
${ }^{1}$ Above-ground shoots that grow from the roots or base of the trunk. "Suckers" are undesirable as they take energy from the main plant and turn it into weak growth in the wrong place.

${ }^{2}$ The Designated lands are lands the members of a First Nation have agreed to lease for the purposes set out in the designation. Designated lands remain reserve lands. A designation is voted on by the members of a First Nation according to the rules of the Indian Referendum Regulations (AANDC, 2012).
} 
In 1975, CIDL signed a Head Lease with Aboriginal Affairs and Northern Development Canada (formerly Department of Indian and Affairs and Northern Development). The Head Lease grants exclusive use of the lands to the lessee, CIDL. The term of Head Lease is for a 50-year period, from May 1, 1975 to April 30, 2025.

The Chippewa Industrial Park has been developed in a phased approach. Phase One was completed in 1991). Phase Two of the Industrial Park has been planned as a 235 acre "eco park" for businesses that are keen to work together to reduce their environmental footprint. It will be developed when future demand and monetary resources permit. Aamjiwnaang undertook a second land designation process in preparation for this second phase of the industrial park. A vote was held on May 11, 2001, however it did not pass. A second vote was held on October 26, 2001, this time passing with a simple majority (Aamjiwnaang Membership Clerk, personal communication, August 2016). Following a long negotiation, the Head Lease for Phase Two of the industrial park was signed on August 24, 2006. The term of this Head Lease is for 99-year period, commencing August 8, 2002 and expiring August 7, 2101. Oversight of Phase Two was originally assigned to Aamjiwnaang Development Corporation (ADC), incorporated in February, 2000. In 2007, the ADC and CIDL band-owned corporations were amalgamated.

The First Nation's economic development model was to develop the industrial park by constructing buildings on a lease back basis. The buildings were leased exclusive of the land. The First Nation's strategy is to maintain control of its own lands to create:

1. employment opportunities for community members;

2. revenues for further development;

3. self-sufficiency for the Band;

4. an environment for partnerships and joint ventures opportunities;

5. an environment to enhance Aboriginal Entrepreneurship; and

6. opportunity to participate in the mainstream Economy.

This economic development model would grow to be one of the strongest and thriving economic branches of Aamjiwnaang.

\section{Implementation process/Cultivating the soil}

Aamjiwnaang began seriously addressing the issue of community planning through the development of the first Comprehensive Community Plan (CCP) in 1985. The CCP addressed a range of traditional planning issues and provided a detailed implementation strategy with significant input from the community through surveys, workshops and public meetings (Monteith \& Brown Planning Consultants, 2014). The CCP established an action plan for all programs and services for the First Nation for the next 20 years; for each area of concern there 
were established goals, objectives, and projects identified. Specifically, for Industrial and Economic Development, the goal was to develop a diverse economic base for the Chippewas of Sarnia Reserve in order to provide stability and long-term employment for Band members. Although there were many objectives explored and developed, many were related to the development of the industrial park with plans for a small commercial plaza, gas station, and restaurant. While the 1985 CCP looked ahead 20 years, it was updated in 1996, partially in 2010, and fully updated in 2014.

To support a community-driven model like this one, you have to have community champions who support the vision and are willing to invest their time. In Aamjiwnaang's case, long-term staff member Tom Maness played this role. He was employed by the First Nation for 34 years, serving as CIDL General Manager and overseeing economic development for the First Nation.

A Development Plan resulting from the $1985 \mathrm{CCP}$ provided the mandate to make availability of and investment in infrastructure a priority for the First Nation. Aamjiwnaang would make many improvements to their lands by providing service roads and municipal services for future business and industry. Without water, sanitary, or storm services, roads and utilities readily available, the opportunities to attract new businesses are significantly limited.

As noted above, the Chippewa Industrial Park was developed in series of phases. Phase 1 is now fully serviced with 14 sites. Phase 2 has one fully serviced site, with the remainder having partial services that will be further developed as market conditions justify expansion, as with Phases 3-5. The First Nation has an agreement with Sarnia Hydro to assume the maintenance of all existing facilities and provide extension of new electricity services, as required. There is an agreement with Union Gas to provide natural gas service to the First Nation and to extend their services to any customer within the industrial area on request. The First Nation has agreements with the City of Sarnia for the maintenance of the sanitary sewage and water distribution facilities within the First Nation, as well as police and fire services.

The Marketing Evaluation section of the report determined that companies in the petrochemical supply chain are most suitable for the First Nation's industrial lands. These may be existing companies interested in expansion or relocation closer to the major industry; new petrochemical related companies locating in Sarnia; manufacturers of consumer products using materials supplied by the petrochemical industries; or industries looking for easy access to the United States, particularly for items used in agriculture. Typical inquiries from industries looking for land or a building to lease included the following: contracting companies; industrial waste processors; chemical companies; automobile bumper manufacturers; transport company depots; light manufacturers; industrial suppliers of seals, pumps, and piping; and fabricators of tanks, vessels, and piping (Jean Monteith \& Associates, 1985).

As part of the planning process, industrial policies were developed and designed to guide the First Nation in the orderly development of industrial uses with the First Nation recognizing the 
zoning for Light Industrial and Heavy Industrial land uses. These policies included maintaining buffer planting (green space) between industrial uses and any residential areas; compliance with all federal, provincial, and municipal standards and regulations; CIDL's approval of sites plans; establishing an Industrial Building Development and Maintenance Fund; collecting a Building Service Levy in lieu of municipal taxes for all leased and privately owned industrial buildings located with Industrial Park; and offering a variety of construction options (build to the tenants specifications, build as "shell" where tenants complete as leasehold improvements, or the industries would build themselves). CIDL had the power to approve site plans.

\section{Turning challenges into opportunities/Pruning the sucker roots}

First Nation communities face many planning and development barriers that municipalities do not. "First Nation communities, by virtue of the Indian Act, are impeded from developing their economies and attracting investment ... as a result of the Act, market forces do not operate properly on Indian lands, thus substantially raising the costs of doing business on reserve. Efforts to modernize outdated and restrictive processes should be supported, expanded and adequately funded" (Stranding Senate Committee on Aboriginal Peoples, 2007, p. ix).

In some instances, a First Nation may have large land holdings, but be capital poor. Many Canadians may be surprised to learn that First Nations do not own their reserve lands, yet this is the reality for First Nations. The underlying ownership of reserve land rests with the Crown and Federal Government, as legislated in the Indian $A c t^{3}$. This will be presented in greater detail later in the paper in reference to Land Designation.

In the case of Aamjiwnaang, it was hoped - through promotional efforts--that the First Nation would be able to attract one additional industry to the Chippewa Industrial Park each year. Each industry would need a new building and in 1985, the estimated cost of constructing one of these buildings was \$200,000 (Jean Monteith \& Associates, 1985). Unfortunately, this goal was not reached. Several industries interested in locating in the Chippewa Industrial Park dropped out due to the inability of the First Nation Band to obtain funding to construct the necessary buildings. Further, it was not possible to obtain a mortgage on the First Nation to build a home prior to securing all the funds in advance of the construction. Similarly, there was reluctance from commercial and industrial developers to start up a business on the First Nation, for fear they would not be able to recoup their assets.

The CIDL General Manager pursued and obtained alternative means of funding for the industrial park's infrastructure and the construction of buildings for lease to industries interested in locating in the park, through capital project grants from Aboriginal Affairs and Northern Development Canada (formerly Department of Indian and Affairs and Northern Development)

\footnotetext{
${ }^{3}$ The Indian Act, enacted in 1876, sets out certain federal government obligations, and regulates the management of Indian reserves land. The act has been amended several times and is administered by the Minister of Indian Affairs and Northern Development. (Source: Assembly of First Nations. www.afn.ca)
} 
and the Association of Reserves For Improving Social Economics (ARISE), among others. As these grants covered only a portion of the costs, Aamjiwnaang, after consulting and receiving direction from their membership, would make an investment from their own source revenues. Negotiations with lenders would also result in funds being obtained by leveraging the revenue generated by the tenant's lease for security.

Aamjiwnaang's Employment \& Training program had developed an excellent relationship with Lambton College in setting up training programs for First Nation members. The First Nation's construction crew, that previously only had experience working on small housing projects, were trained to a capacity level to construct the buildings within the industrial park under the supervision of a General Building contractor. This was a great and proud accomplishment for Aamjiwnaang, meeting the strategic plan objectives to create employment opportunities for community members and environment for partnerships.

\section{CIDL achievements/Bearing fruit}

CIDL is a band-owned company that oversees the management of Phases One and Two of the industrial park. It is run by a Board of Directors (7 directors) serving on a rotating basis, that are annually appointed by the Band Council. Day to day operations are carried out by a management team that play a vital role in attaining the corporate objectives to achieve selfsufficiency by taking full advantage of business opportunities and creating entrepreneurs in a competitive market place.

Aamjiwnaang has been able to successfully achieve over $80 \%$ of the recommended projects identified through previous versions of the Community Comprehensive Plan. The first phase of the Chippewa Industrial Park, with 14 fully serviced lots, is completely full with 17 tenants, half of which are owned and operated by First Nation members. It is home to multinational and international corporations with Intertec Instrumentation (a fibreglass building and enclosure manufacturer), American Railcar Industries (a railcar repair and maintenance facility), and Qualwash (a tank truck cleaning facility) as the major tenants. The industrial park also includes a Petro-Can gas bar. The First Nation shares a special arrangement with Petro Can, where the First Nation owns the gas bar, with a lease to Petro-Can who in turn hires a band member to operate the business. There is also a small business plaza which accommodates CIDL's corporate head office, a restaurant, and a variety of native small businesses. In addition, CIDL owns Structural Tech Corporation, (STC) an award winning metal fabricator that ventured into the renewable energy sector. STC owns companies that have partnered in renewable projects under the Ontario's Feed-in-Tariff (FIT) programs and have been successful in being awarded 20-year FIT contracts.

In 2010, at the $17^{\text {th }}$ National Annual Conference of the Council for the Advancement of Native Development Officers (CANDO), CIDL received the Community Economic Developer of the 
Year Award in recognition for their commitment and dedication to improving the standards of living and prosperity in the communities which they serve.

Some of the key reasons for the success of CIDL include capitalizing on a strategic geographic location, an educated workforce, low employee benefits costs, and access to an array of markets. Other assets include Aboriginal procurement opportunities, tax benefits for industries and businesses, low land costs, good infrastructure, effective management, continuity within the Board of Directors, a good reputation, and the fact that existing tenants provide strong references for new tenants. CIDL General Manager Tom Maness stated that: "Our low turnover in tenants has much to do with our approach to treating them as business partners. By building and leasing our properties in the industrial park, we have allowed our tenants to use their financial resources to modernize their equipment, and expand their market base. In addition, the use of employment resources has led to long term employment for First Nation members, with many companies in the industrial park placing a priority on recruiting Aboriginal workers" (personal communication, December 2010).

Direct impacts of the Chippewa Industrial Park include:

- Total and annual combined sales of \$150 million in the mainstream economy;

- Creation of 300 jobs;

- A reduced unemployment rate historically equal to the national average rate;

- Increased longevity of Aamjiwnaang entrepreneurs (including a Aboriginal Achievement Award winner);

- Development of export products for local, regional and international markets (such as the United States, Turkey, Germany and the Middle East);

- Generation of First Nation revenues for the development and expansion of the community centre and for the new youth and seniors complex;

- Support for Phase 2: a 235 acre Eco industrial Park; and

- Enhancement of the overall quality of life both on the First Nation and the community at large (T. Maness, personal communication, December 2010).

\section{Options for moving forward with the expiry of the Head Lease}

CIDL, under the authority of the Head Lease which expires on April 30, 2025, has entered into leases with their tenants under Phase One of the Industrial Park. Some of these tenant leases are nearing expiry dates. Some tenants have expressed interest in extending their current lease or renewals beyond CIDL authority of April 2025. While CIDL is currently in negotiations with 
two new potential tenants, it makes it difficult not to be able to offer a lease beyond 2025, especially when longer terms are being requested. An inquiry was made to Aamjiwnaang's legal counsel (Ron Rowcliffe Q.C, Barrister \& Solicitor, personal communication, April 6, 2016) regarding CIDL's predicament. He advised that he knew of no easy solution. While a prospective customer is likely to be concerned by security of tenure, he advised CIDL to avoid making any representation beyond the expiry date of the Head Lease. He further advised that the Band Council should engage in discussions with the AANDC lands department regarding this matter prior to the expiration date of the Lease the land reverting to Reserve status.

The longer the Head Lease issue goes unresolved, the more it will continue to constrain the business that CIDL can conduct and limit future business opportunities.

The Aamjiwnaang CCP of 2014 (Monteith \& Brown Planning Consultants, 2014) has identified this issue as a high priority for Business and Economic Development. It identifies the need to proactively consider the requirements for re-designation and/or negotiating the lease on the Industrial Park.

In December 2015 a preliminary discussion was held with Aboriginal Affairs and Northern Development Canada (AANDC) Lands Department staff, and Aamjiwnaang's Economic Development staff and Lands Management Officer to explore options available to the First Nation. AANDC advised for the continued operation of CIDL and that one option for the First Nation would be to undergo another Land Designation. AANDC had indicated that the current Head Lease could not be re-negotiated nor could Phase One of the industrial park come under the Head Lease for Phase Two (that has a 99-year term). The Federal regulation and policies of land designation does not allow the First Nation to add "land" to a designation, it only makes provision for taking "land" out of a designation and that it must be done by Band Council Resolution.

What is a Land Designation? When a First Nation wants to lease reserve land to another party, the Indian Act requires the land to be designated for leasing. A designation identifies an area of land for a certain use or purpose and for a certain period of time. When a piece of land is designated it does not lose reserve status; its tax exempt status remains intact, and once the term ends the land reverts back to the First Nation. Before a lease of First Nation-held lands can be considered, the First Nation electors must consent to giving up their use, rights and interests in the lands. This consent is obtained by way of a referendum vote where a majority of the electors must vote and a majority of those voting must vote in favour of the proposal. As stated by the National Aboriginal Economic Development Board (2013, p. 12): "Imagine Canada having to hold a referendum every 40 years on the Parliament buildings' location. Now imagine all the local businesses who have built their future on the location of these buildings and leaving their future up to a referendum. It is disruptive to the community and economies."

Land designation is a six stage process: 
1. Assessment: AANDC verifies the land tenure and confirms the land is suitable to be designated. The First Nation submits a Band Council Resolution (BCR) requesting a designation, vote, date, and appointment of an electoral officer.

2. Planning and Budget: AANDC reviews the BCR and opens a file with the Department of Justice for the preparation of designation documents.

3. Documents: land appraisal, land surveys, environmental review, negotiation of Draft Lease terms - AANDC reviews all documents in consultation with the Department of Justice.

4. Preparation: a voters list is prepared for First Nations both on and off-reserve, and voting packages prepared.

5. Lead up to Vote: a Notice of Referendum is posted, packages mailed to off-reserve members, and Community information session is held.

6. Vote: the vote is conducted and a simply majority of voters must be in favour of the designation. If the vote is successful, AANDC prepares the required documents to complete the Designation.

An alternative AANDC option to negate the need of Land Designation would be to bring the leasing property under the authority of the AANDC's Land Management Regime.

The First Nation Lands Management Regime gives First Nations more control over their reserve lands and resources by allowing them to opt out of the 34 sections of the Indian Act related to land management. Under the Regime, First Nations develop their own laws to manage their reserve lands, including laws governing land designations, environmental protection and matrimonial real property. First Nation Land Management Act (FNLM) is the only example to date, of federal legislation that has been enacted to provide a basis for sectoral self-government by First Nations as an alternative to the Indian Act Regime (AANDC, 2012).

In 2009, through the Federal Framework for Aboriginal Economic Development, AANDC (2009) introduced the Reserve Land and Environment Management Program (RLEMP). The RLEMP is a program governed by the Indian Act which is intended to enhance capacity in First Nations to manage their own lands and environment resources on its reserves and to assume responsibility for Indian Act land management activities on behalf of the Minister of Aboriginal Affairs and Northern Development. The RLEMP program's key functions are community land use planning, lands and natural resources transactions, environmental management, and compliance management. There are three levels of responsibility that a First Nation can function at within the regimes: Training and Development Level; Operational Level; and Delegated Authority Level.

Currently, Aamjiwnaang First Nation lands are administered under the Reserve Lands Environmental Management Program (RLEMP) by the Lands Management Officer at the first level of Training and Development. As Aamjiwnaang assumes more control for the management 
of their lands, they will eventually reach a decision point to determine if they too will join the growing movement across Canada of First Nations that are opting out of the Indian Act in developing or operating land laws in the Regime FNFM. Aamjiwnaang's experiences of the Land Designation in 1974 and again in 2001 is that the process is both complex and time consuming, that had taken approximately five years from the start to the end. This time factor creates a significant difference of the "speed of business" and the "speed of government" which can have a negative impact an economic development. It is worth noting that there have been some significant efforts made by AANDC to streamline the lands designation process by amending the Indian Act to reduce the voting threshold and authorize the Minister of AANDC, rather than the Governor in Council, to grant approvals.

Given these amendments, Aamjiwnaang's experience gained through previous designations, and the time constraints of the Head Lease expiry date designation, it may be sometime before Aamjiwnaang is in a position to implement their own laws under FNLM. Should the First Nation develop their own land management laws, they would need to ensure to complete due diligence on environmental laws and practices in order to minimize the risks and liabilities that they would be held accountable for in the industrial park. As an interim measure, the land designation option may be best for Aamjiwnaang. To initiate the land designation process now could lead to a smoother transition between the current Head Lease and the implementation of the new Head Lease.

\section{Conclusion}

Forty-five years later, after tilling and preparing the soil, planting the seed (a vision), and nurturing it, on-going maintenance and development has resulted in Aamjiwnaang's economic development model, "a Healthy Tree" becoming a reality of a thriving industrial park. As CIDL grows, in near future it will look to develop the "eco park" Phase 2. CIDL will continue to face challenges, turning them into opportunities for business development that would align Aamjiwnaang's corporate goals and objectives with that of potential partners and investors. The economic development staff is consistently looking to identify and nourish relationships with potential business partners in the public and private sectors.

Building on the successes of a good development model of economic development and political stability, the First Nation has developed partnerships with wind and solar developers. Aamjiwnaang and Bkejwanong First Nation, (formerly known as Walpole Island First Nation) have jointly entered into a 50/50 partnership with Northland Power Inc. on a Grand Bend Wind Farm (100 Megawatt). It has reached commercial operation as of April of 2016. Aamjiwnaang also has a 25\% ownership in a partnership with Suncor Energy on the Adelaide Wind Farm (40 Megawatt). It has reached commercial operation as of January 2015. Aamjiwnaang is currently in negotiations for another 60 Megawatt wind farm project to have a $50 \%$ ownership. These new developments will become a major revenue source for the First Nation over the next 20 years. 
Aamjiwnaang's economic development model is bearing fruit, containing seeds that leave a legacy for future generations to come.

\section{Author biography}

Carole Delion has been employed by Aamjiwnaang the First Nation for 27 years, the past 13 years as the Business Development Officer promoting the economic, business development, working with aboriginal entrepreneurs, and assisting in the management of the Chippewa Industrial park. She serves as the Secretary/Treasurer to Aamjiwnaang's owned corporations. She is a member of the Aamjiwnaang management team that has developed two large renewable energy wind partnerships. She is member of Ontario First Nation Economic Developer Association (OFNEDA), Council for Advancement of Native Development Officers (CANDO) and a PAED graduate. She has received her Economic Development Program certificate at the University of Waterloo. She has been married for 37 years and is a proud parent, and grandparent of two grandchildren Aiden and Ella!

\section{References}

AANDC (2009). Federal Framework for Aboriginal Economic Development. Retrieved from https://www.aadnc-aandc.gc.ca/eng/1100100033498/1100100033499

AANDC (2012). First Nations Land Management Regime -Guide for First Nations.

Chippewas of Sarnia Industrial Developments (2010). About Us. Retrieved from http://www.cidl.net/aboutus.html

Jean Monteith \& Associates (1984). Chippewas of Sarnia, Community Profile Report.

Jean Monteith \& Associates (1985). Chippewas of Sarnia, Comprehensive Community Plan.

Monteith \& Brown Planning Consultants (2014). Aamjiwnaang First Nation Comprehensive Community Plan, Background Report.

National Aboriginal Economic Development Board (2013). Addressing the Barriers to Economic Development on Reserve. Retrieved from http://www.naedb-cndea.com/reports/addressingbarriers-to-economic-development-on-reserve.pdf

Stranding Senate Committee on Aboriginal Peoples (2007). Sharing Canada's Prosperity-A

Hand Up, Not a Hand Out. Retrieved from http://www.parl.gc.ca/content/sen/committee/391/abor/rep/rep06-e.pdf 